\title{
A TÖRTÉNELMI GALÍCIAI ÚT TOKAJ-HEGYALJAI SZAKASZA ÉS BOLTOZOTT KÖHÍDJAI
}

\author{
VÁSÁRHELYI BALÁZS \\ Okl. építőmérnök, műemlékvédelmi szakmérnök, PhD, BME Építőanyagok és Mérnökgeológia Tanszék \\ E-mail: vasarhelyib@freemail.hu
}

\begin{abstract}
A Bodrog jobb partján, a Tokaj-Eperjesi-hegység keleti lábánál futó régi ún. Galíciai út szerves része volt a korabeli magyar úthálózatnak: egyik szakasza volt a Galícia kereskedelmi és gazdasági központját, Lemberget (mai nevén L’vov) Pesttel összekötő útnak. Sárospataktól Szegilongig haladva Tokaj-Hegyaljához tartozó településeken vezet át ez az alig 16 km hosszúságú történelmi útszakasz, melyen ma is nyolc boltozott kőhíd áll. Ezen kőhidak közül három csúcsíves kialakításával nemzetközi tekintetben is egyedülálló. A cikkben az útszakasz mellett ezen hidakat mutatjuk be, geometriai kialakításukat és jelenlegi állagukat. A cikk célja, hogy felhívja a figyelmet erre a viszonylag érintetlenül megmaradt történelmi útszakaszra.
\end{abstract}

Kulcsszavak: Galíciai út, Tokaj-Hegyalja, boltozott kőhidak, történelmi úthálózat

„... Amikor az angyalok látták, hogy az emberek nem tudnak átkelni a mélységeken és a szakadékon, és nem tudják munkájukat elvégezni, kiterjesztették szárnyukat, $s$ az emberek az angyalszárnyakon át kezdtek egyik pontról a másikra járni. Így tanulták meg az angyaloktól, hogyan kell hidat épiteni. A forráskutak mellett a legnagyobb áldás a hidak épitése, s a legnagyobb bün hozzányúlni ezekhez a hidakhoz, mert minden híd egy-egy angyal örizetében áll..." Ivo Andric: Híd a Drinán

\section{BEVEZETÉS}

Városaink, községeink meghatározó elemei a folyókon, patakokon átívelő hidak. Ezek az építmények sokszor a település szimbólumává is váltak, gondoljunk például Magyarországon a veszprémi viaduktra, a budapesti Lánchídra, Szabad- 
ság hídra vagy Erzsébet hídra, de ide sorolható a hortobágyi Kilenclyukú híd is, mely tájegységének vált jelképévé. Ez nemzetközileg is igaz, például a londoni Tower-, a New York-i Brooklin-, a San Francisco-i Golden Gate vagy az avignoni híd esetében. Nem véletlen ezért, hogy a mostari helyreállítások a település központjában lévő híddal kezdődtek.

Számos híd viszont megbújik környezetében, az arra járók sokszor észre sem veszik, szerves részei a rajtuk futó útnak. Ezen hidak többsége kőből vagy téglából készült, boltozott kialakításúak, mellyel kisebb vízfolyásokat, árkokat hidalnak át. ${ }^{1}$ Ilyen kőhidakkal Magyarország egész területén találkozhatunk, számuk meghaladja a háromezret. A fontosabbakat Gáll (1970) összegyüjtötte, és könyvében ismerteti kutatási eredményeit. ${ }^{2}$

A ma használatos 37-es úttal párhuzamosan, a Bodrog mellett futó régi, falvakat összekötő út eredete a homályba vész. Kétségtelen tény, hogy a tokaji borok már a középkorban igen megbecsültek voltak, így a kereskedelem miatt az utat többé-kevésbé mai vonalvezetésében használhatták. Hogy milyen hidak is lehettek itt, arról első információnk 1832-ből származik, amikor császári rendelettel Magyarország összes vármegyéjében össze kellett írni a harcászati szempontból fontos utakat; ehhez kapcsolódóan a hidakat is megemlítik, sok esetben részletesen le is írják azokat.

Szegilongról indulva, Sárospatakig menve, ezen az alig több mint $15 \mathrm{~km}$ hosszú szakaszon nyolc boltozott kőhíd áll, melyek közül három már csak alakjánál fogva is kitünik csúcsíves boltozatával. Ez az alak önmagában is kuriózum, ugyanis ilyen szerkezetű hidat sem Magyarországon, sem Európában nem szoktak építeni - Magyarországon az itt bemutatott csúcsíves hidakon kívül a kisdörgicsei hidat soroljuk ebbe a kategóriába, de az szerkezetileg eltér az itt felsoroltaktól, ugyanis inkább falazási hibából kifolyólag válhatott csúcsívessé. Ugyanakkor a félköríves boltozatú hidak is külön figyelmet érdemelnének.

Jelenleg Magyarországon nincs egyetlen utunk sem védelem alatt (Máté 2005). Az utak megmaradt elemei sokszor a mai korszerü hálózatok nyomvonalán fekszenek, melyeket elfed az új paraméterekkel alakított és vezetett, burkolt gépkocsiút. Számos olyan régi út is van, amelyet vonalvezetésének alkalmatlansága, egykor volt hálózati logikájának megszünése miatt felhagytak, ma már csak gyalogos ösvény vagy földút. Kutatók ma még csak elvétve foglalkoznak a régi utakkal és mútárgyaikkal mint múszaki, táji emlékekkel. ${ }^{3}$

1 Ezek történetét legújabban Medved (2001) foglalta össze.

2 A könyvet csak 1970-ben sikerült kiadni, de kutatása-megírása már 1960-ban befejeződött. A boltozott kőhidak legújabb kutatási eredményeit az Országos Hídügyi Konferencia keretében megjelenő kötetek tartalmazzák.

3 Ezt a hiányt próbálja pótolni Máté Zsolt a BME Építészmérnöki Kar Műemlékvédelmi Szakmérnöki Szak „Történelmi települések értékvédelme” című tantárgya keretén belül tartott előadásaival, melyekben külön foglalkozik a történelmi úthálózatokkal. 
Fontos megemlíteni, hogy a történelmi utakkal részletesen először Györffy (1943) foglalkozott. Napjainkban Blazovich László és Jancsó Árpád nevét kell feltétlenül megemlíteni - mindkettőjük dél-magyarországi utakkal foglalkozik, Blazovics a mai magyarországi résszel, míg Jancsó a temesi utakkal-hidakkal. Hiánypótlók a Magyar Hídügyi Konferencia megyékre kiterjedő összefoglalásai is, ${ }^{4}$ melyek az adott hidakat az úthálózatban betöltött szerepükön belül ismertetik, jelentős történeti áttekintéssel. A jelenlegi magyarországi hídállományról részletesen Gyukics és Tóth (2005) ad áttekintést.

A bemutatott útszakasz védelmét, rajta lévő mütárgyaival együtt, érdemes lenne végiggondolni (Máté 2005, Vásárhelyi 2001).

\section{A TOKAJ-HEGYALJAI ÚT MINT A RÉGI „GALÍCIAI ÚT” RÉSZE}

A leírt útszakaszt nagyon sokáig a ,galíciai útszakasz” részeként ismerték: a galíciai országút kiépítését a XIX. század elején a bécsi kormány és a magyar Helytartótanács is következetesen sürgette. Ez az út Pestről Gyöngyösön keresztül Miskolcra, majd onnan Szerencsen és Sátoraljaújhelyen keresztül vezetett tovább Galíciába Munkácson és a Vereckei-hágón át. Az út egyike volt a Monarchia legfontosabb felvonulási útjainak. Ez a szakasz békében a birodalom (később a Monarchia) és Oroszország közötti kereskedelem fejlődését, esetleges háborús konfliktus esetén pedig a hadseregek mozgósításának biztosítását szolgálta. (Például 1849-ben ezen az úton jöttek be az Ausztriával szövetséges cári seregek a magyar szabadságharc leverésére, de még az első és a második világháború alatt is katonailag meghatározó jelentősége volt, mivel a keleti hadseregmozgások ezen bonyolódtak le.)

A régi galíciai út vonalvezetése sok helyen megegyezik a mai főközlekedési utakéval, számos helyen viszont (a települések elkerülése céljából) új utakkal váltották ki. Ahol megszünt a forgalom, ott sokszor már csak a megmaradt hidak emlékeztetnek arra, hogy ott valamikor egy elsőrendủ út haladt, míg ahol felhasználták a régi vonalvezetést, ott a megnövekedett terhelés miatt általában új utakat építettek.

A Pestet Lemberggel összekötő út szakaszaiban természetesen már létezett a bécsi kormányrendelet előtt, az inkább rendezte és összefogta a meglévő útszakaszokat, illetve a hegyvidéki részeken kiegészítette. Ahol szükségessé vált, új hi-

\footnotetext{
4 Eddig az alábbi megyék kötetei jelentek meg (évszámmal): Győr-Moson-Sopron (1993), Borsod-Abaúj-Zemplén (1994), Békés (1995), Hajdú-Bihar (1996), Pest megye és Budapest (1997), Heves (1998), Bács-Kiskun (1999), Jász-Nagykun-Szolnok (2000), Komárom-Esztergom (2001), Tolna (2002), Csongrád (2003), Zala (2004), Somogy (2005). A köteteket dr. Tóth Ernő szerkeszti. Jelenleg a Nógrád megyei kötet áll előkészítés alatt.
} 
dakat, átkelőket építettek. Ennek az útszakasznak több kisebb vízfolyást kellett áthidalnia, mivel északról a Tokaj-Eperjesi-hegység zempléni része szegélyezi, amelyből a lefolyó vizek (patakokban vagy ideiglenes vízfolyásokban) az úttól délebbre lévő Bodrogba torkollanak. Valószínúsíthető, hogy ezek áthidalására az első időben fahidakat építettek, és fokozatosan tértek át a sokkal masszívabb, az időjárásnak ellenállóbb kőhidakra. Nagyobb árvizek, áradások esetén ezek a hidak minden bizonnyal károsodtak, tehát átépülhettek, esetleg a régi anyag felhasználásával újat építhettek.

\section{AZ ÚTSZAKASZ A KATONAI FELMÉRÉSI TÉRKÉPEKEN ÉS AZ 1832-ES ÚTÖSSZEÍRÁS}

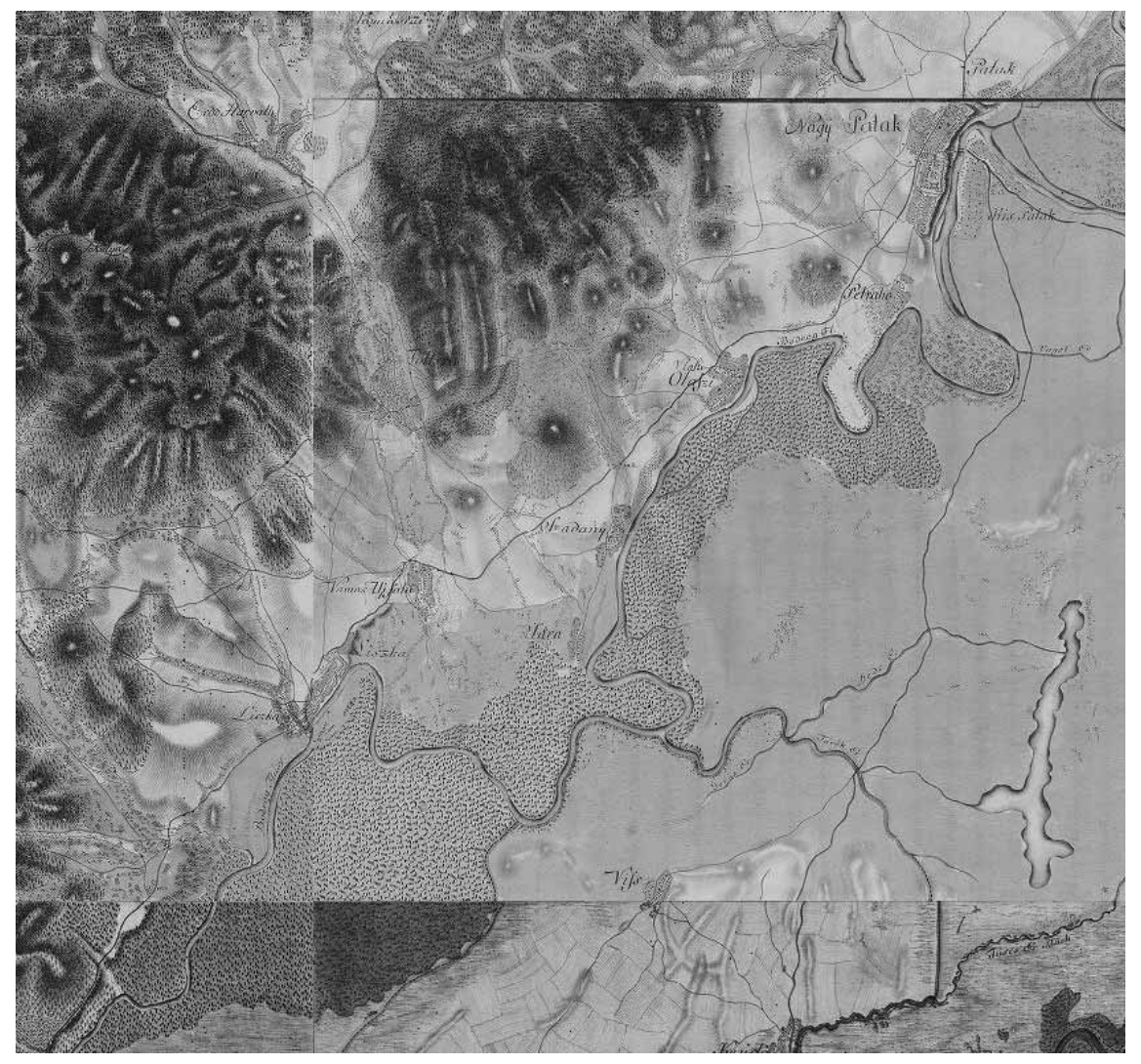

1. ábra. A Galíciai út vizsgált szakasza az első katonai felmérési térképen 


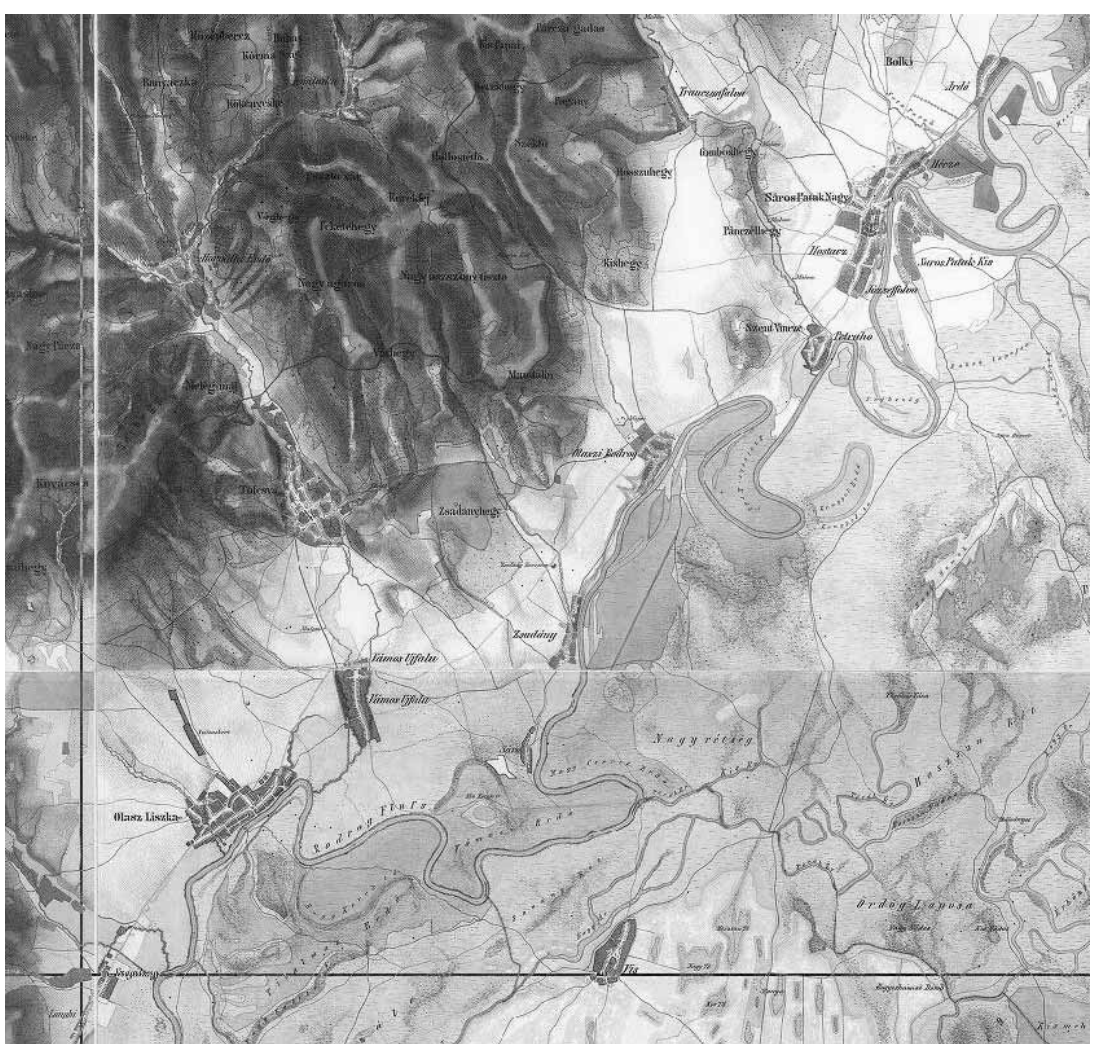

2. ábra. A Szegilong-Sárospatak útszakasz a második katonai felmérési térképen

Az útszakaszon található hidakról először közvetve csak az első bécsi katonai felmérés (1782-1785) térképeiről kaphatunk információt (lásd 1. ábra). Mind ezen, mind a második katonai felmérési térképen (ezen a szakaszon 1857-ben készült el - lásd 2. ábra) a vízfolyásokat, árkokat áthidaló hidakat jelölik, de természetszerüen (a térkép céljának ,megfelelően”) nem adnak információt azok geometriai adatairól, továbbá anyagukra sem lehet belölük következtetni. A térképek alapján valószínúsíthető, hogy a katonai szempontból (is) jobban megfelelő kőhidak már akkor megépültek, jóval hamarabb, mint ahogy a galíciai útvonalat véglegesítették. A két katonai térképen az útvonal vonalvezetése között nincsen különbség, az megegyezik a maival.

Első pontosabb adatunk mind az útszakaszról, mind a hidakról az országosan 1832-ben elrendelt megyei út- és hídösszeírás alapján van. Ennek Zemplén vármegye 1833-ban tett eleget. ${ }^{5}$ A latin nyelvü irat a fontosabb kereskedelmi (és hadi)

5 Minden vármegye eleget tett ennek a rendeletnek, Heves vármegye kivételével - ott 1803ban, 1847-ben és 1853-ban történtek hídösszeírások. 
útszakaszokat írja le, megjelöli, hogy mennyire vannak kiépítve, továbbá - főként katonailag fontos - megjegyzéseket tartalmaz. A hidakra vonatkozó megállapítások általában ebben a rovatban szerepelnek, megadva helyüket, néhány esetben hosszukat is, valamint katonai szempontból állagukat, építési anyagukat.

\section{BOLTOZOTT KÖHIDAK SZEGILONGTÓL SÁROSPATAKIG}

A hidakat Szegilongból indulva, Sárospatakig haladva mutatjuk be, ${ }^{6}$ felhasználva Gáll (1970) kutatási eredményeit, valamint a helyszíni terepbejárásnál tett megfigyeléseket.

Szegilong: Rátérve a régi „galíciai” útra, rögtön az első településen két híd is található.

Az első híd (6 + 200 km szelvénynél, 3. ábra), mely 15,5 m hosszú, a már a bevezetésben említett kuriózumok közül az egyik: 2,85 m-es, egynyílású, csúcsíves szerkezetű. Annyiban más, mint a többi, hogy itt a csúcsív nem erősítőív (mint a többi hídnál), hanem maga a boltozat csúcsíves (mely nagyon kecses hatást ad). A híd szárnyfalai igen masszívak. Az északi (befolyási) oldalon fokozatosan, míg a déli (kifolyási) oldalon lépcsőzetesen vastagodnak. Ívmagassága a padlószinttól a csúcsig a déli (kifolyási) oldalon kb. 1 méterrel magasabb, mint az ellenkező oldalon (4, illetve 3 méter). Mellvédfalai és szárnyfalai az úttengelyhez képest enyhén széttartók, középen két kerékvető jelzi a legkeskenyebb helyet, ahol a mellvédek egymáshoz töréssel csatlakoznak. A mellvédfalakra mindkét oldalon valószínúleg az 1960-as években betonhabarcs fedést helyeztek el. E fedés számos helyen már repedezett, az alatta lévő kősor pedig fokozottan mállott. A jelenlegi úttengely nem egyezik meg a hídtengellyel, ami későbbi útrendezés következménye. A katonai térképek jelölik, és az 1833-as Zemplén megyei út- és hídösszeírásban is szerepel: mint kőhidat említik.

A másik híd ( $7+378$ km szelvénynél) háromnyílású, félköríves szerkezetü, már a falu külterületén van (4. ábra). Néhány helyen erdőbényei hídként tartják számon, mivel a Bényei patak felett vezet el, valamint e mellett van az erdőbényei leágazás. A patak igen bővizü, de lassú folyású, hordalékos, aminek hatására a meder oly mértékben feliszapolódott, hogy a boltvállakat szinte teljesen betemette. Víz a középső mederben folyik, a másik kettő csak igen magas vízállás esetén ereszti át a vizet.

\footnotetext{
6 A környéken található többi hídról bővebben lásd: Hidak Borsod-Abaúj-Zemplén megyében (1994), illetve Vásárhelyi (2005).
} 


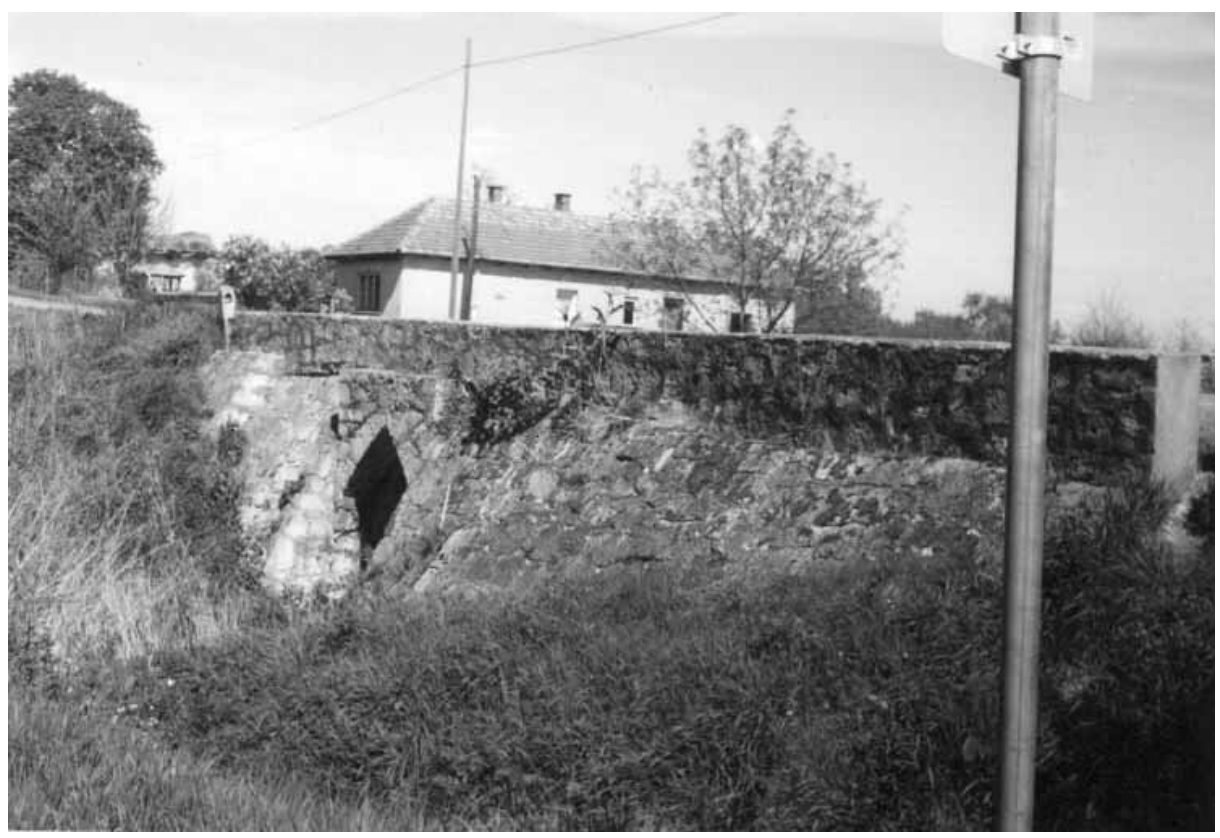

a)

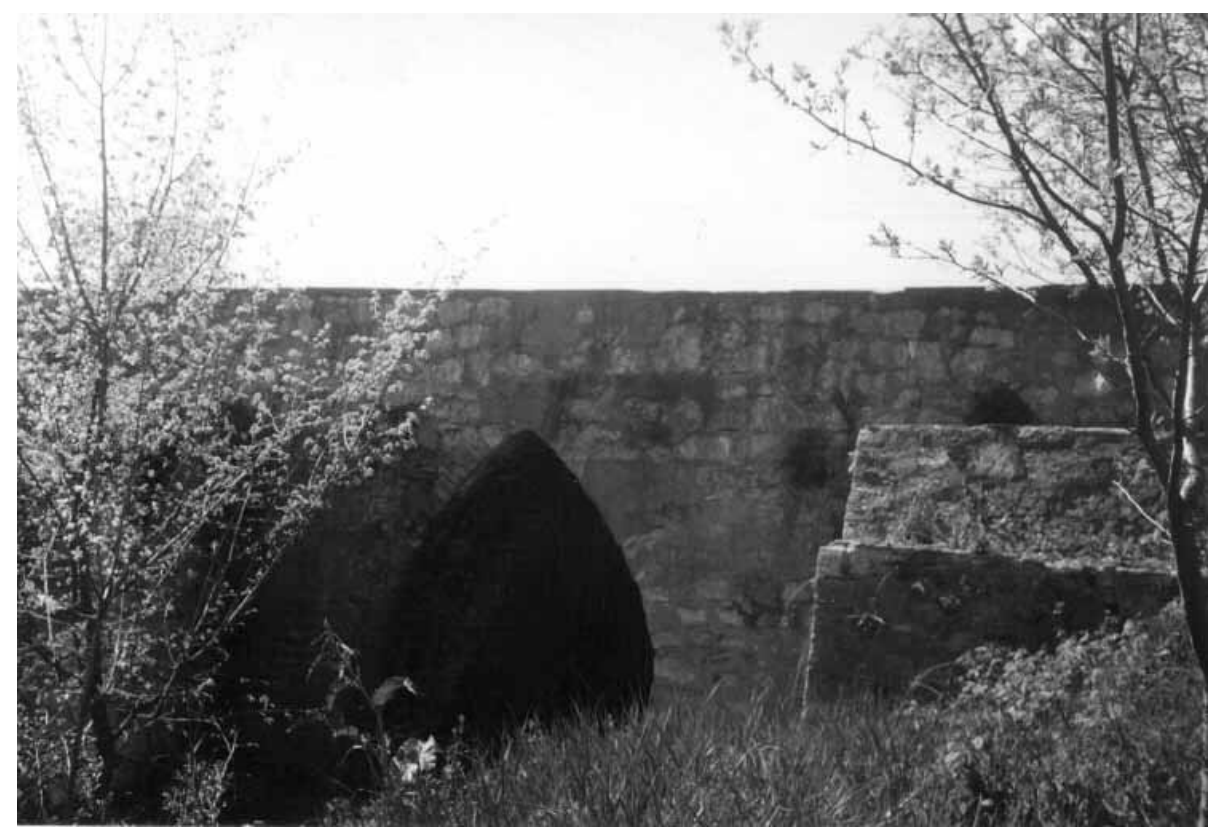

b)

3. ábra. Szegilongi kőhíd a $6+200$ km szelvénynél - a) befolyási oldal, b) kifolyási oldal 


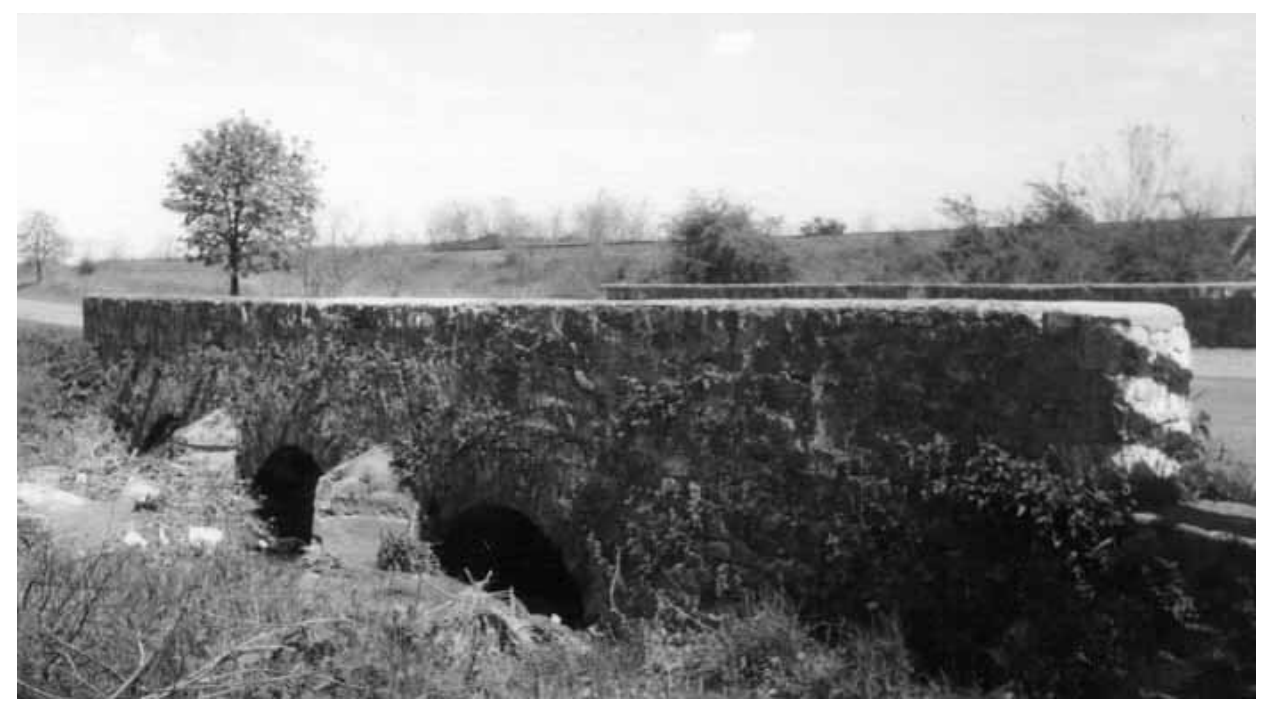

a)

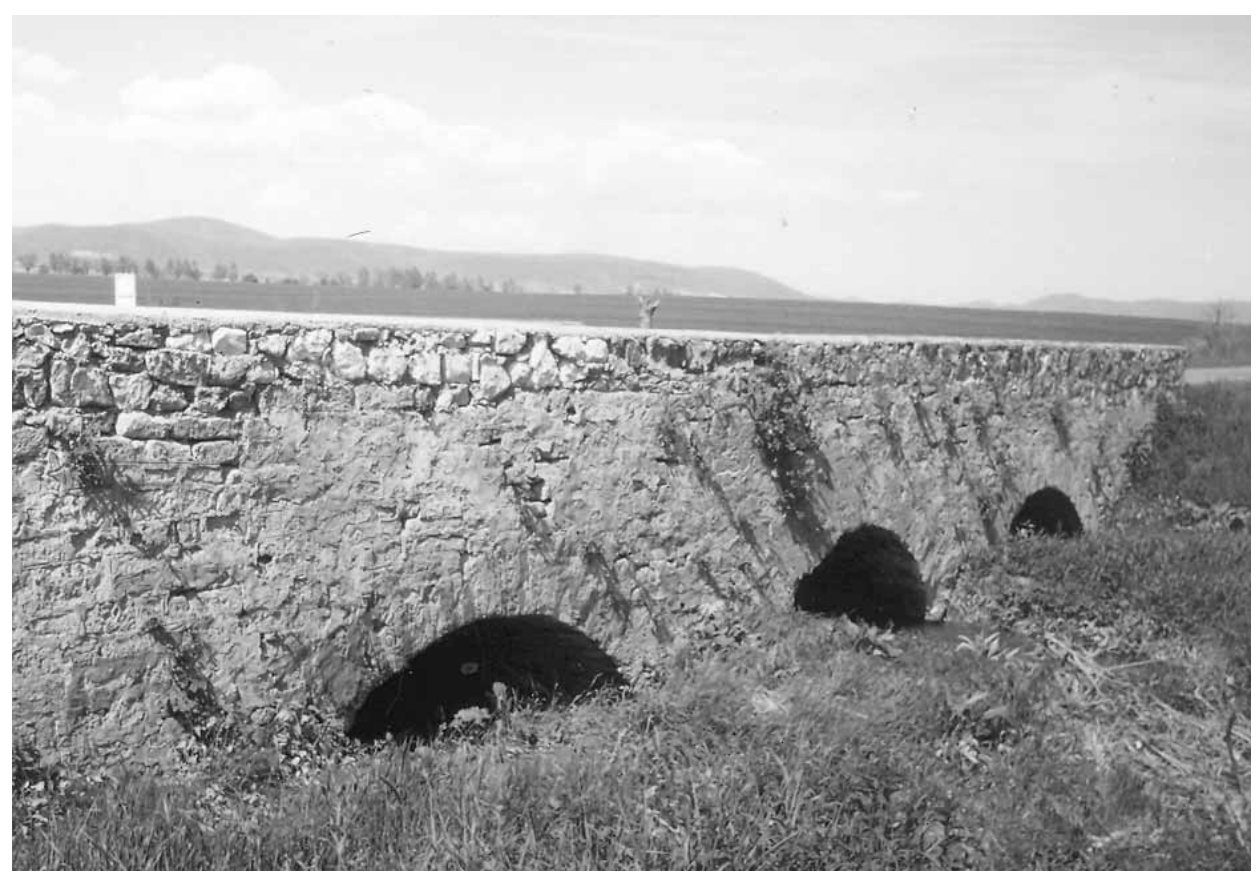

b)

4. ábra. Szegilong területén, a $7+378 \mathrm{~km}$ szelvényben épült híd a) befolyási és b) kifolyási oldala 
A vízfolyás felőli északi oldalon a híd homlokfalát a két mederpillér háromszög alakú toldata tagolja (jégtörő toldatok), melyeken betonfedés van. A kifolyási oldalon (déli oldal) a homlokfal sík. A pillértoldatokon fedkövek vannak, mint ahogy a mellvédfalakat is bizonyára fedkövek takarhatták valamikor. Az 1833-as megyei hídösszeíráskor a híd háromnyílású kőhídként lett felvéve. ${ }^{7}$ Teljes hossza $22,5 \mathrm{~m}$.

Olaszliszka: Az útszakasz egyik legmonumentálisabb, leglenyügözőbb hídja $(10+709$ km szelvénynél), mely múemlék jellegü védettség alatt is áll (5. ábra). A több mint 40 m hosszú, csúcsíves híd meredek oldalesésú szakadékot (ideiglenes vízfolyást) hidal át. A terep erős esése miatt a befolyási (északi) oldalon a félköríves dongaboltozat záradéka kb. 2 m-rel van a terep felett, míg ez a magasság a kifolyási (déli) oldalon a $8 \mathrm{~m}$-t is meghaladja.

A kis nyílásmérethez $(2,7 \mathrm{~m})$ képest a tekintélyes hosszúság a híd magas fekvésének a következménye. A hegy felőli oldalon szárnyfal nélküli rézsüje van, a völgy felöli oldalon négy bordával erősített magas szárnyfala, amely párhuzamos az úttengellyel.

Mellvédfalai a híd közepe felé fokozatosan emelkednek, melyeket a legmagasabb ponton (középen) egy-egy 1,10 m magas kőrózsa díszített. Ezek a díszek mára csak csonkjaikban maradtak meg. Az 1960-ban készített fénykép tanulsága szerint (Gáll 1970) a déli oldali szobor ekkor még megvolt.

A dongaboltozat, amely a hídpályát hordozza, a hídpálya alatt vízszintes alkotókkal van átvezetve, és bár a híd déli homlokfalának síkjában el van falazva, körvonala jól kivehető. A boltozatot a homlokfalaknál és még öt közbenső helyen bordák támasztják meg, amelyek közül a két észak felőli félköríves, az öt dél felőli pedig csúcsíves.

Olaszliszkán az első katonai felmérés nem jelölt hidat, annak ellenére, hogy a térkép jól láthatóan igen nagy méretủ vízbevágást mutat. A második katonai felmérés viszont két hidat is feltüntet, melyek közül a település északi felén lévő már nincs meg.

A híd méretei, arányai és kialakítása folytán elgondolkodtató, hogy híd szerepén túl nem töltött-e be más funkciót is - esetleg nem használták-e az útszakasz védelmében bástyaként vagy egyéb katonai létesítményként. Az 1833-as felmérésben mint kőhidat írják le, ${ }^{8}$ de ennél több információt nem közölnek.

\footnotetext{
7 ,Pons lapideus at tres apperturas singula $=3^{\circ}$ in latitudine, 5 org. longus exstructus habetur...”, azaz „A kőhíd háromnyílású, széltében $3^{\circ}, 5$ öl hosszan építtetett...”.

8 „A rivo Bartamas per Oppidum Liszka usque pontem lapideum in superiori fine oppidi, structum 575 org.” - azaz „A Bartamas folyótól kezdve Olaszliszkán át a falu felső végén lévő kőhídig kiépítve 575 öl".
} 


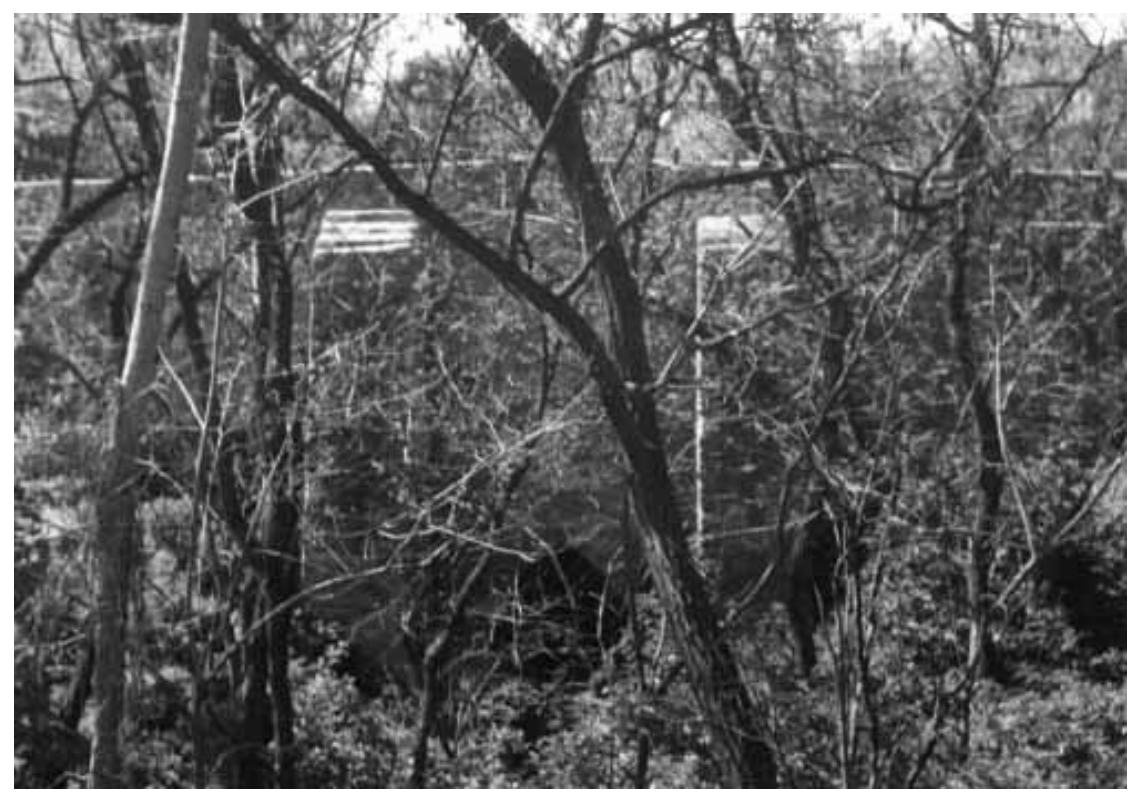

a)

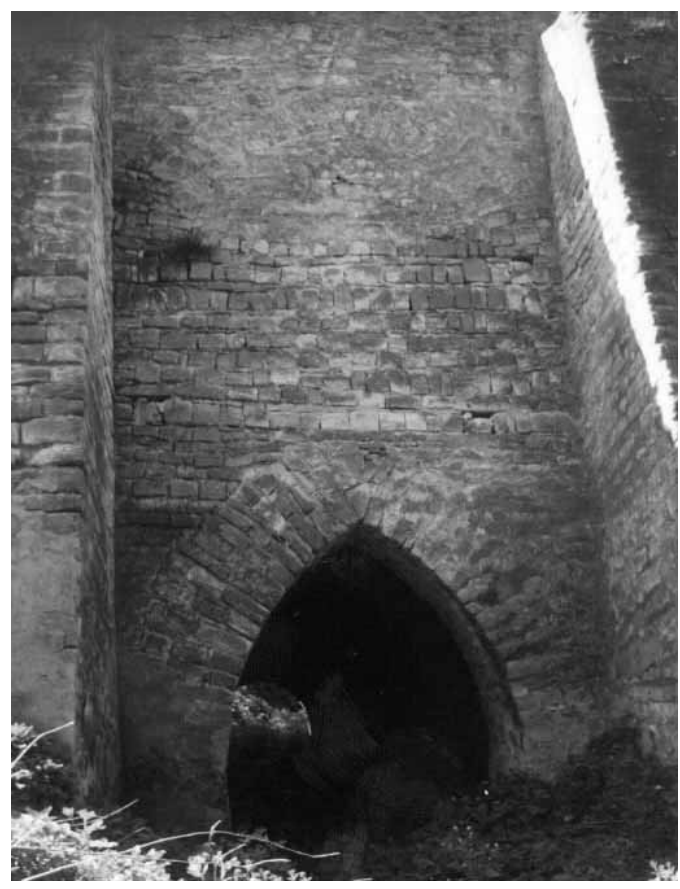

b)

5. ábra. Az olaszliszkai „híderődítény” távoli és közeli képe 


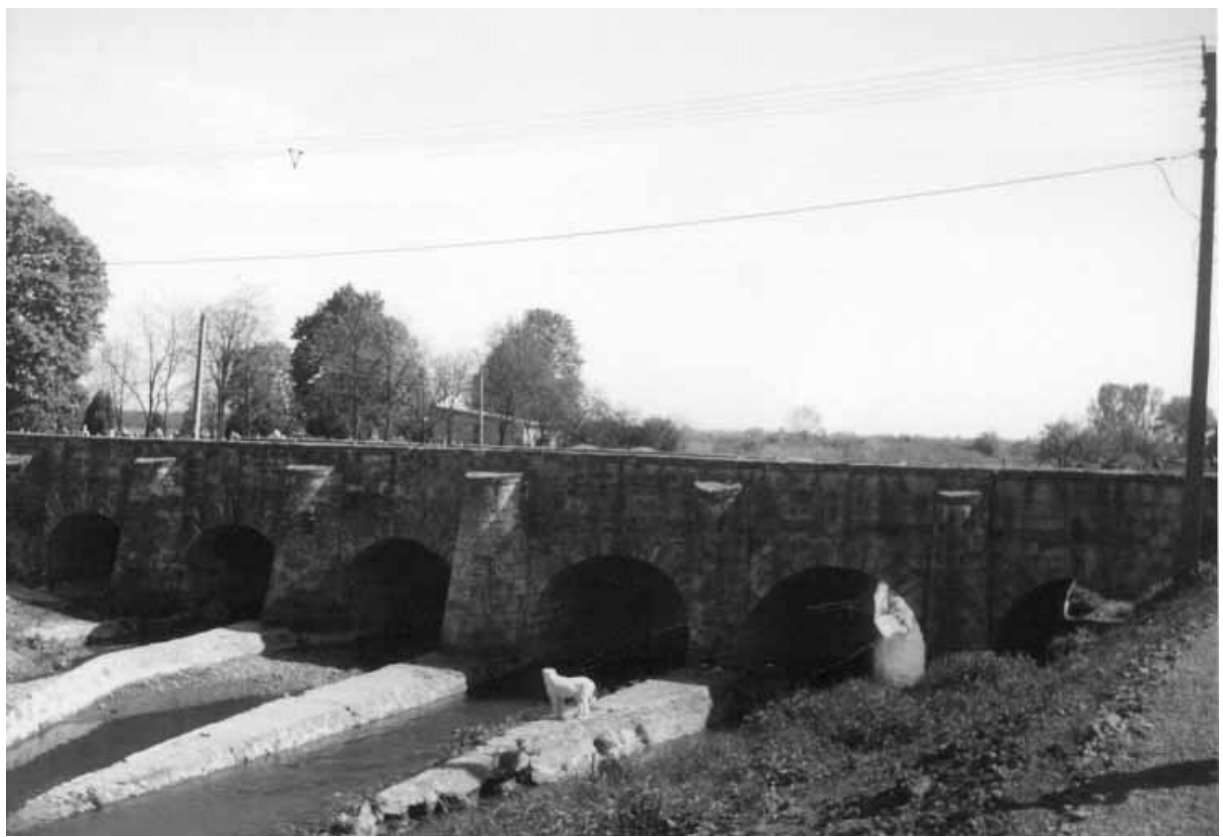

a)

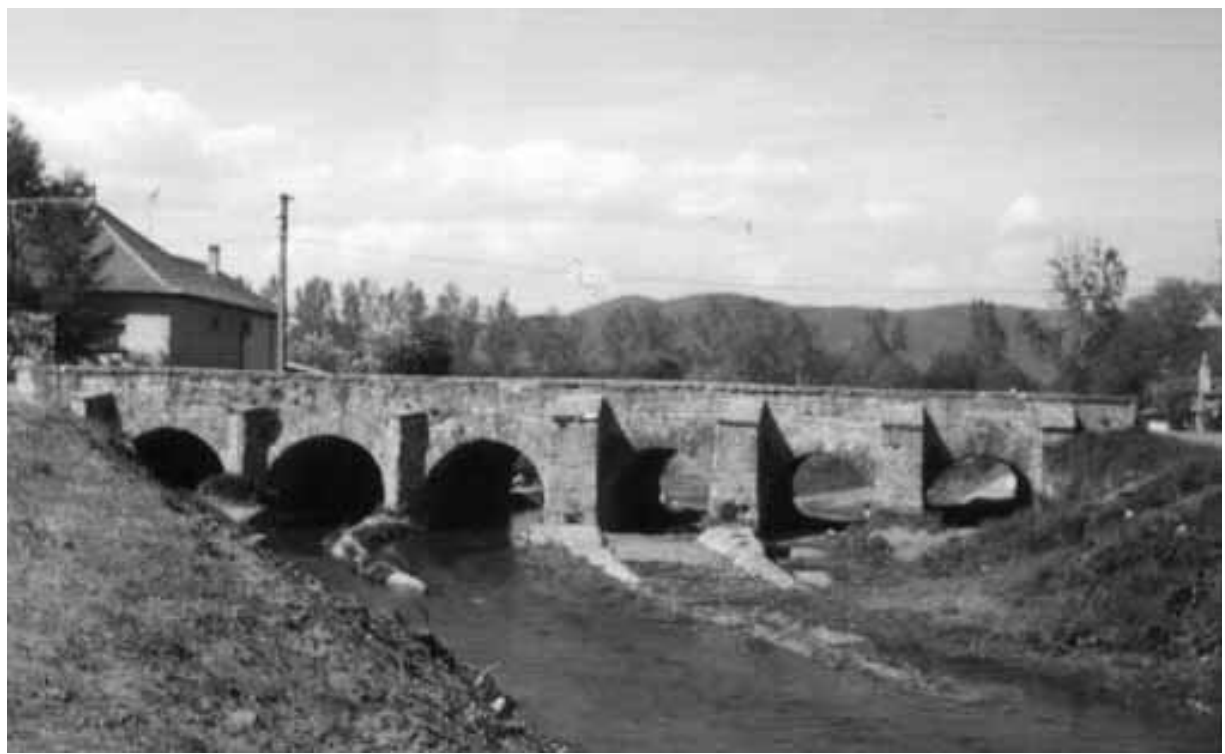

b)

6. ábra. Vámosújfalu múemléki védelem alatt álló hídja a) északról (befolyási oldal) és b) délről (kifolyási oldal) 
Vámosújfalu: A 30 m hosszú, hatnyílású, müemlék jellegű híd $(13+800 \mathrm{~km}$ szelvénynél) az igen bővizü Tolcsva-patak áthidalására épült (6. ábra). A patak mind a híd előtt, mind az után vízterelőkkel szabályozva van. Nyugatról a második és harmadik nyílás alatt folyik általában a víz, mely nagyobb vízállás esetén (a terelők segítségével) fokozatosan a többi nyílást is használja.

A nyugat felőli két pillér toldatai mindkét homlokfalazaton jóval kisebbek a többinél. A toldatok az északi (befolyási) oldalon minden esetben lekerekítettek, míg a déli (kifolyási) oldalon csak a nyugati oldalon lévő három toldat lekerekített, a keleti oldalon lévők nem. Az öt mederpillér és két parti pillér (hídfö) fedkövekkel van lefedve. 1981-ben részben át kellett építeni, mivel az egyik nyílás beszakadt egy teherautó alatt. Az átépítéskor a boltozatok fölé teherelosztó vasbeton lemez került, amivel a teherbírást jelentősen megnövelték.

Az első és második katonai felmérések Vámosújfaluban 3 hidat is jelölnek, melyek közül csak a Tolcsva-patakot áthidaló maradt fent - a másik kettő helye a térképek alapján nehezen meghatározható. Helyszíni bejárás alapján, a térkép léptékét is figyelembe véve lehet a valószínü helyükre következtetni. Egy másik, 1797ből való térképen már szintén meglévő hídként szerepel (a térkép a Nagy-Tolcsvapatak faúsztatásra való felhasználása céljából készült). Az 1833-as Zemplén vármegyei út- és hídösszeírásban ötnyílású kőhídként van feltüntetve, így valószínúsíthető, hogy a XIX. században kibővítették. Jelenleg múemléki védelem alatt áll.

Sárazsadány: A 8,6 m hosszú, egynyílású híd (16 + 800 km szelvénynél) Bodrogolaszi község előtt, a sárazsadányi elágazásnál található, ezért néhány helyen mint bodrogolaszi hidat említik (7. ábra).

A híd a Magyarországon fellelhető négy csúcsíves híd egyike, boltozata mindkét oldalon jól látszik. A hídfóket mindkét oldalon két-két támborda erősíti. A mellvédek felső vonala vízszintes, alaprajzi elrendezése egyenes.

Az első katonai felmérési térképen jelölik (Sárazsadány = Szadany) a falu külterületén lévő hídként, de az 1833-as megyei hídösszeírásban nem tesznek róla említést (valószínúleg kis mérete miatt).

Bodrogolaszi: Bodrogolaszi területén két híd található.

Az első híd (19 + 819 km szelvénynél) kétnyílású, teljes hossza 10,2 m (8. ábra). Az áthidalt ideiglenes vízfolyás északi oldala növényekkel benőtt, míg a déli viszonylag rendezett - itt a gyalogos- és bicikliforgalom számára külön híd épült, ami sajnos teljes mértékben eltakarja a régi hidat. A két híd között még egy gázvezetéket is átvezettek. Az így megvalósult állapot sajnos közel sem nevezhető esztétikusnak. A hídpálya viszonylag magas az árok medermélységéhez képest. Ennek következtében a híd hídfőit és pilléreit a kifolyási oldalon (délkeleti oldal) 


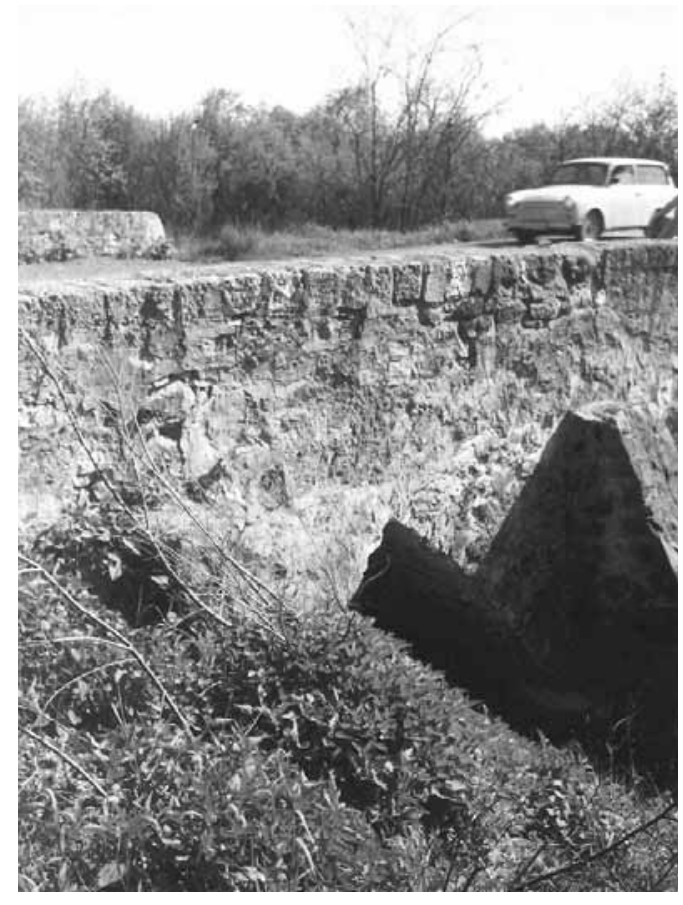

a)

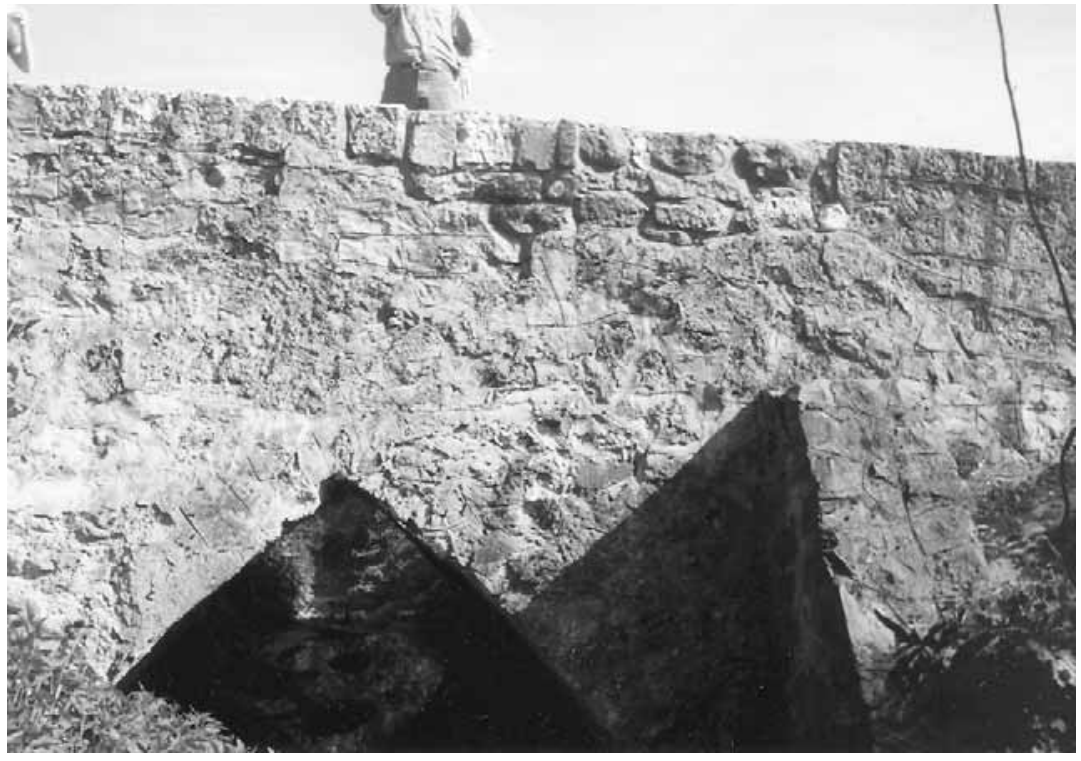

b)

7. ábra. A sárazsadányi híd $a$ ) befolyási és $b$ ) kifolyási oldala 


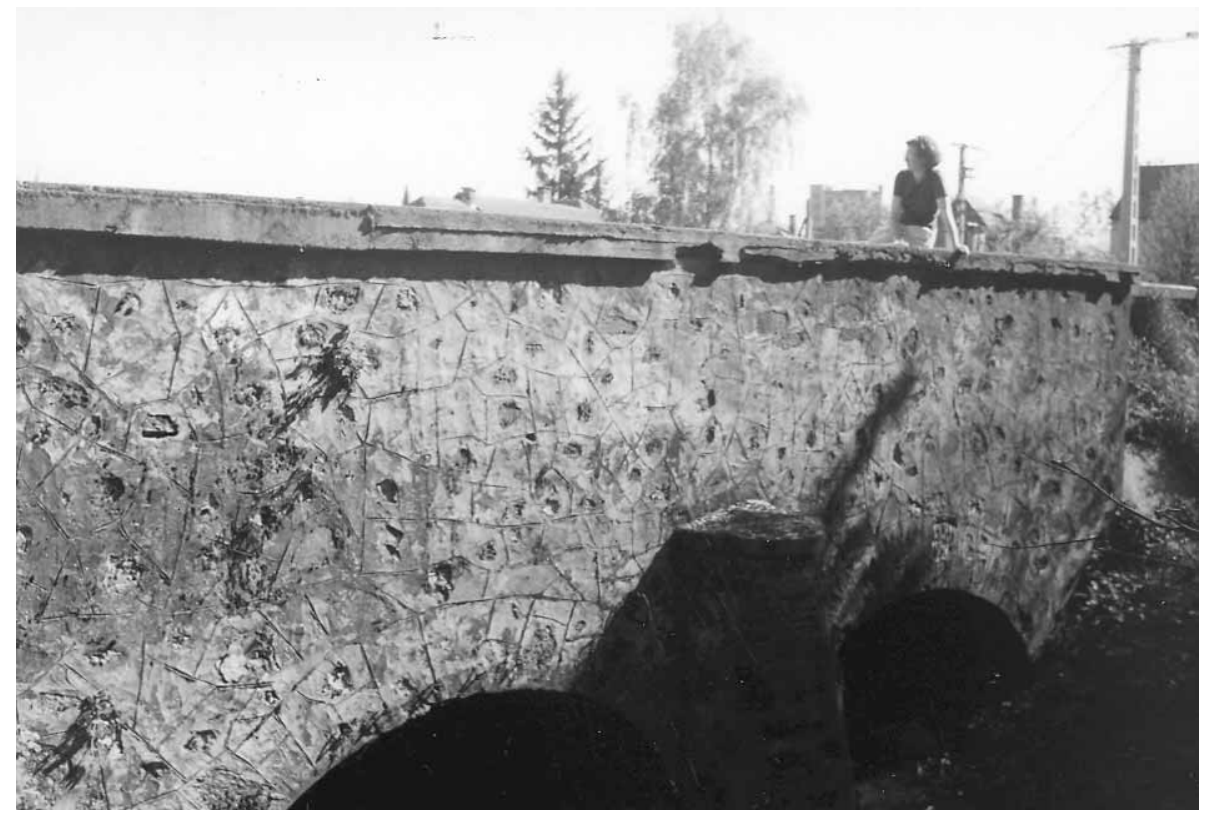

a)

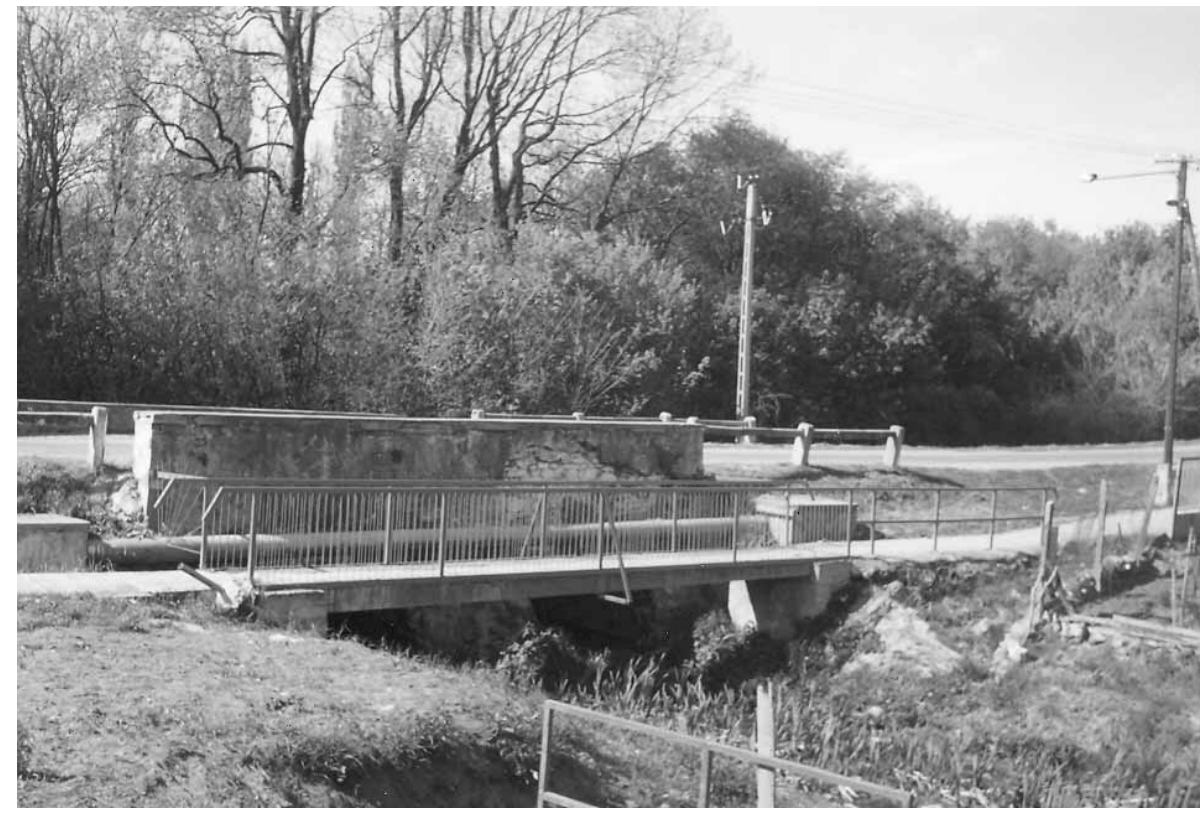

b)

8. ábra. A Bodrogolaszi belterületén található híd két oldala 
egy-egy támbordával erősítették meg. Az ellentétes oldalon a pillérnek csak a szokásos toldata nyúlik ki a homlokfal síkjából.

Az első katonai felmérési térképen jelölnek Bodrogolaszi (akkori nevén Vlahi Olaszi) belterületén hidat, viszont az 1833-as megyei hídösszeírás nem tesz róla említést.

A Bodrogolaszi keleti külterületén lévő másik híd $(20+607$ km szelvénynél) 13 m hosszú (9. ábra). Az egynyílású híd mindkét oldalán két-két támborda erősíti a hídfőket, melyek méretei egyezőek. A támbordák szépen tagolják az egyébként sík homlokzatot. Az egyenes mellvédfalak vízszintesek. Az első katonai felmérési térképen nem jelölik. A Zemplén megyei utak és hidak 1833-as összeírásakor a hidat feltüntették. ${ }^{9}$ Ez alapján a híd a Kuliz-éren ível át. Bár ezt a földrajzi nevet ma már nem használjuk, mégis ezzel azonosítható, mivel Bodrogolaszi és Sárospatak között csak ez az egy híd van. Az említett két kisebb híd valószínüsíthetően elhanyagolható méretủ műtárgy lehetett, melyek az útrendezéssel megszüntek.

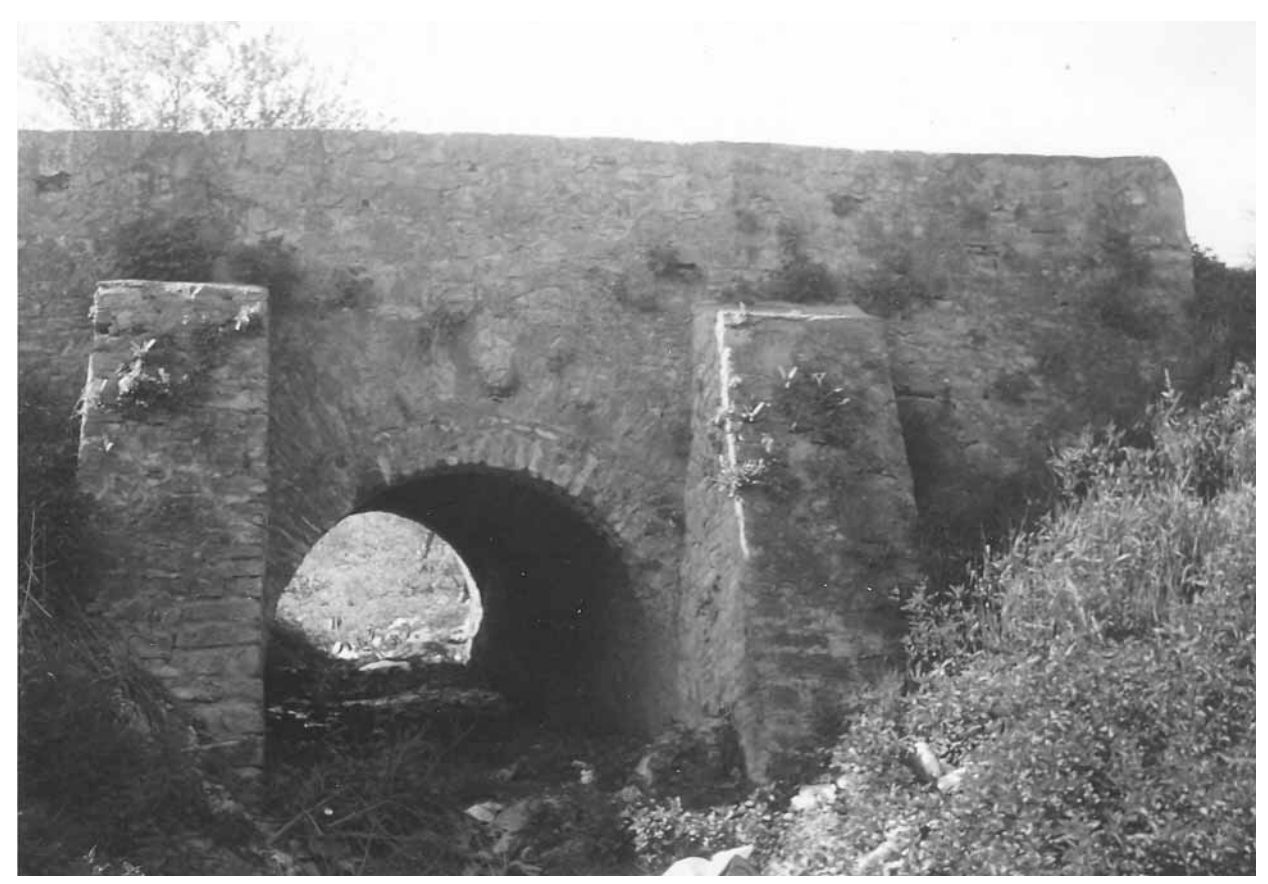

9. ábra. A bodrogolaszi külterületén lévő híd

9 „Inter Olasi et Patak unus maior in Kuliz ér et duo minores ponticuli lapidei existant”, azaz „Olaszi és Patak között a Kuliz-érnél egy nagyobb és két kisebb kőhíd áll”. 


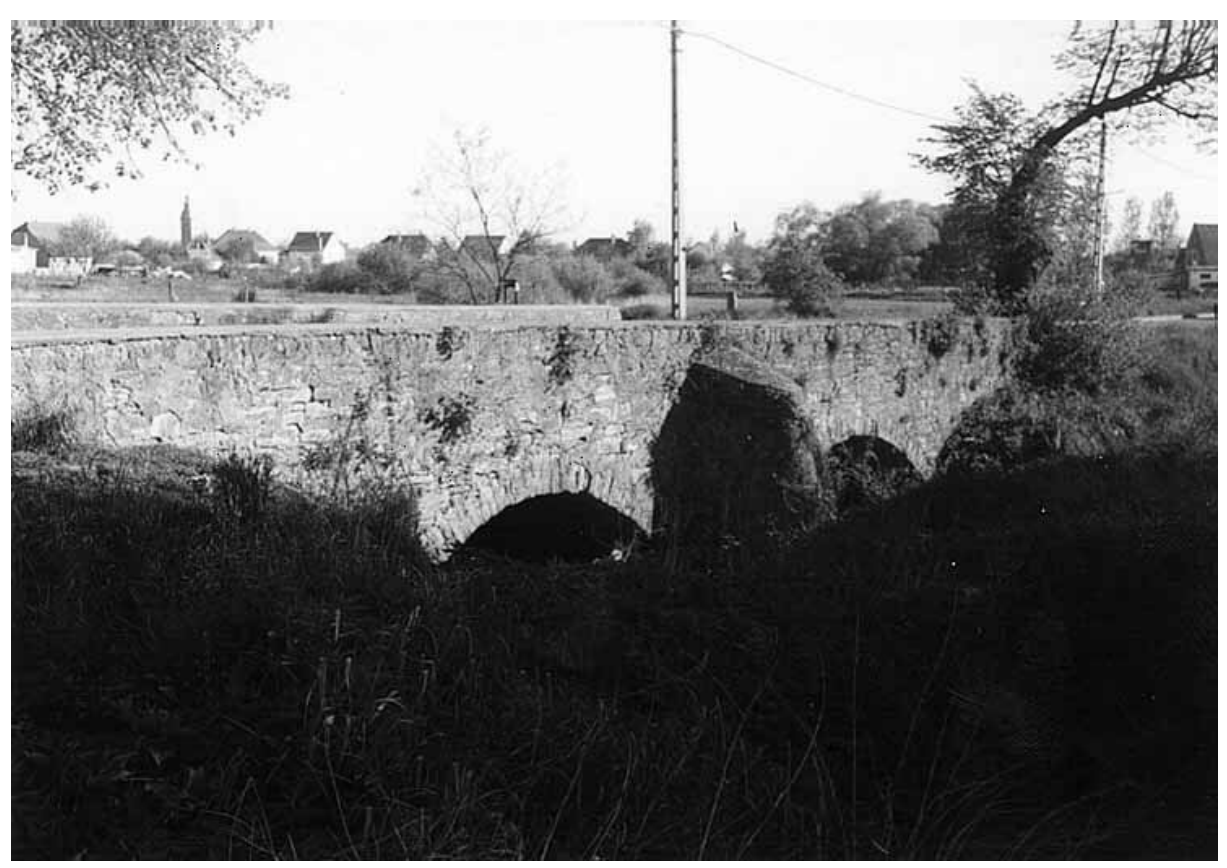

10. ábra. A Sárospatakon lévő, már funkcióját vesztett, boltozott kőhíd

Sárospatak: A Sárospatak nyugati határában (annak belterületén) található kétnyílású híd (21 + 925 km szelvénynél) a régi Hercegkúti-patakot keresztezte (10. ábra). 1985-ben az Észak-Magyarországi Vízügyi Igazgatóság rendezte a vízfolyást, melynek során a meder áthelyezésre került kb. 300-400 m-rel Bodroghalász felé. A híd kifolyási és befolyási oldalán is földgátat emeltek, ezért jelenleg a hídnak semmilyen funkciója nincs, de mint müemlék megmaradt. Pilléreit mindkét oldalon félkör alaprajzú támborda erősíti. A mellvédfalak egyenes vonalvezetésüek.

Az első katonai felmérési térképen jelölik (Nagy Patak külterületén, Petraho és Patak között félúton), és az 1833-as Zemplén megyei híd- és útösszeírás is említést tesz itt egy kőhídról, de bővebben nem tér ki rá.

\section{A HIDAK ANYAGA}

A vizsgált útszakasz minden hídját ugyanabból a jól megmunkálható szürkésfehér színű riolit tufából építették. Ez a Zempléni-hegységben bányászott kőzet igen jó minőségü építési kőanyag, olyannyira, hogy ebből építették például a Hortobágyi hidat is. Ezt a helyi kőanyagot minden bizonnyal a közeli Erdőbényén bá- 
nyászhatták, amely kőfaragóiról is ismert volt (Fehér 1997). Innen szállították el durva megmunkálás után, majd a helyszínen végezhették el a finom megmunkálást. Néhány esetben ugyancsak helyi kőanyagból (andezitből) egészítették ki a mellvédfal sérüléseit, de a javítások a XX. század második felétől jelennek csak meg. Ezek mind anyagukban, mind megmunkálásukban idegen elemek. A kő sok esetben eltérő mechanikai tulajdonsága miatt roncsoló hatás is jól láthatóan megjelenik. Ajánlatos ezek megvizsgálása és esetleges cseréje.

Fel kell hívni a figyelmet a mellvédfalakra, melyek nagy valószínűséggel mindenütt fedkővel voltak fedve, viszont napjainkra számos helyen cementhabarcssimítást kaptak. Sajnos ez a két anyag - különböző mechanikai tulajdonságaikból adódóan - tönkreteszi egymást, aminek nyomai jól láthatók néhány hídon. Ezért Gálos és Vásárhelyi (2005) ajánlatot dolgozott ki a kőanyagok helyszíni vizsgálatára és dokumentálására, mely a későbbi múemléki helyreállítást megkönynyítheti.

\section{6. ÖSSZEFOGLALÁS}

Sárazsadány és Sárospatak között a régi galíciai útszakaszon nyolc boltozott kőhíd áll. Ezek közül három csúcsíves, ami mind Magyarországon, mind nemzetközi viszonylatban unikumnak számít. A boltíves szerkezetűek is említést érdemelnek karcsúságukkal, kiképzésükkel. Régóta felvetett kérdés, mióta is állhatnak ezek a hidak. Erre a levéltári kutatások alapján sajnos nem lehet választ adni. Az első dokumentum, amellyel a hidak létére következtethetünk, az első bécsi katonai felmérési térkép, mely az 1780-as években készült. Itt csak a hidak esetleges meglétéről kapunk információt. Ezen térképek a mai hidak közül csak az olaszliszkai és a bodrogolaszi külterületén lévő hidat nem tüntetik fel. Megjegyzendő, hogy a térkép Olaszliszkánál jelöli a bevágást, rajta az út keresztülhalad, tehát a híd megléte valószínűsíthető, míg Bodrogolaszinál az adott szakaszon semmilyen terepi egyenetlenséget nem mutat a térkép. Érdekesség még, hogy Vámosújfalu belterületén az első katonai felmérési térkép másik két hidat is jelöl, amelyekről semmilyen információnk nincsen.

Az első pontos írásos felmérést az 1833-as Zemplén megyei út- és hídösszeírás tartalmazza. Itt két hidat nem említenek (feltételezhetően méretük miatt): a bodrogolaszi belterületén lévőt és a sárazsadányit.

A második katonai felmérési térkép, melyet ezen a szakaszon 1857-ben készítettek, már az összes hidat feltünteti. Érdekesség, hogy Olaszliszka és Vámosújfalu területén itt is jelölnek olyan hidakat, amelyek ma már nem állnak.

A fentiekből következik, hogy a hidak építési idejére csak következtetni lehet. A Zempléni-hegység déli lejtői (Tokaj-Hegyalja) a XIII. században a francia 
(vallon) telepesek megjelenése után indulnak jelentős fejlődésnek. Feltételezhető, hogy valamilyen módon már abban az időben is megoldották a települések közötti szállítási kapcsolatokat, tehát a jelenlegi hidak helyén minden valószínűség szerint álltak valamiféle hidak. A vizsgált útszakasz minden bizonnyal a XVI. században, mai állapotához közel épülhetett ki, ugyanis ez az az idő, amikor a tokaji bor a régión túl is ismertté válik - annak szállítása, forgalmazása alapvető érdeke volt a vizsgált településeknek.

Természetesen felvetődik a hídalak alapján való datálás lehetősége. Valószínüsíthető, hogy a különböző ív alakú hidak különböző korokból származnak.

- A csúcsíves hidaknál feltételezhető, hogy egy időben épültek. Ezt valószínúsíti az a tény, hogy a Magyarországon található 4 csúcsíves híd közül három épült itt, gyakorlatilag egymás mellett, melyeknek a nyílásszélessége szinte teljesen megegyező (2,7 m körüli, azaz 1 öl és 3 láb). Feltételezhető továbbá, hogy az 1833-as út- és hídösszeíráskor a sárazsadányi híd már állt, csak méretei miatt nem említették meg (ezt alátámasztja az a tény is, hogy az első katonai felmérési térképen jelölik a hidat). A hídalak, illetve a kialakítás annyira eltérö a hazai és a nemzetközi gyakorlattól, továbbá statikai szempontból sem indokolt (sőt, inkább előnytelen), hogy minden kétséget kizáróan nem híddal foglalkozó szakember tervezte és építette azokat, hanem olyan helyi kőművesek, akik építkezhettek a környékbeli templomoknál. A forma alapján így elképzelhető, hogy a hidak eredete a középkorra nyúlik vissza. Itt külön ki kell emelni az olaszliszkai hidat, mely méreteivel és arányaival elüt az összes többitől, és feltételezhető, hogy építési ideje jóval korábbi. A tág környezet geomorfológiai adottságait is figyelembe véve esetleg nem csak hídfunkciót látott el, hanem valamilyen mértékben védelmit is.

- A félköríves boltozatú hidak építési ideje a XVIII. századra valószínűsíthető. Az 1807-ben az Építési Főhatóság által kiadott típusterv kiképzései és részletmegoldásai megegyeznek a vizsgált útszakaszon található hasonló hidakéval azok nyílásszámától függetlenül. Mivel egy híd megépítése több év munkája, továbbá az 1780-as térképen már szerepelnek, így minden bizonnyal jóval régebben épülhettek itt hidak, melyeket esetlegesen átépítettek.

Végezetül: egy híd soha nem ragadható ki környezetéből, azzal szervesen együtt „él”. A tiszta, rendezett környék kiemeli a híd szépségét, és plusz színfoltot adhat a falunak, településnek (Tóth 1998). Fontos lenne ezért nemcsak a hidak, hanem az azokhoz tartozó úthálózat védelméről is gondoskodni (Máté 2005). Ehhez szükséges lenne az út mentén még fellelhető régi kilométerkövek, útszéli feszületek stb. felvételét is elvégezni, azokat dokumentálni, védelmükről gondoskodni. 


\section{KÖSZÖNETNYILVÁNÍTÁS}

A szerző köszönetet mond az OTKA F 43291. számú kutatásnak a cikk megírásában nyújtott segítségért.

\section{IRODALOM}

Fehér János (1997): Az erdőbényei köfaragó-mesterség története. Herman Ottó Múzeum évkönyve, XXXV-XXXVI.

Gáll Imre (1970): Régi magyar hidak. Müszaki Könyvkiadó, Budapest.

Gálos Miklós-Vásárhelyi Balázs (2005): Közúti boltozott kőhidaink. Kö 7(2): 21-25.

Györffy István (1943): Magyar falu - magyar ház. Budapest. Reprint: Budapest 1987.

Gyukics Péter-Tóth Ernő (2005): Hidak Magyarországon. Budapest.

Hidak Borsod-Abaúj-Zemplén megyében (1994). Miskolc.

Máté Zsolt (2005): Történeti települések értékvédelme. Jegyzet, BME Építészmérnöki Kar Müemlékvédelmi Szakmérnöki Szak.

Medved Gábor (2001): Történetek a világ hídjairól. Terc Kiadó.

Tóth Ernő (1998): A hidak megóvása és műemléki védelme. 28. Egri nyári egyetem előadásai 1998. június 30. - július 8. 73-77.

Vásárhelyi Balázs (2001): Boltozott köhidak a régi galíciai út Szegilong és Sárospatak közötti szakaszán. Müemlékvédelmi Szakdolgozat, BME Építészmérnöki Kar.

Vásárhelyi Balázs (2005): Zemplén közúti hídjai a Tiszán és a Bodrogon. Zempléni Múzsa 5(3): 43-47.

\section{THE HISTORICAL ROAD UNDER TOKAJ-MOUNTAINS AND ITS BRIDGES}

\section{Summary}

The goal of this paper is to present a short part of one of the historical roads in Hungary, between Szegilong and Sárospatak, in Zemplén county (North-East Hungary). This nearly 16 kilometers long road at the right part of the Bodrog River was one of the oldest "army-road" of the Hungarian Kingdom and the Monarchy and it can be using today, as well. During the centuries it was linked Pest and Lemberg (capital of Galicia, now Lvov, Ukraine) - using by the merchants during the peace and soldiers during the wars. It was used in both world wars and the revolutions $(1848,1956)$ by the Russian armies, as well. The history of this road is not well-known documented - probably it was existed during the $16-17^{\text {th }}$ century, but the first documentation was written only at the beginning of the $19^{\text {th }}$ century.

There are eight arch bridges on this road; three of them were built with a very specific pattern, which is unique both in Hungary and Europe. The paper shows the history and the present state of these bridges. The first documentation about these bridges was at 1833, when all the bridges of the county were documented.

Unfortunately, the preservation of the road does not exist - the aim of this paper is to attack an attention.

Keywords: Galicia army road, historical road, arched bridge, Tokaj-mountains 
